\title{
Research on the Management of Scientific Research Funds in Private Colleges and Universities
}

\author{
Aihua Zhang \\ Department of economics and management, Wenhua College \\ aiwa0716@163.com
}

Keywords: Private colleges and universities; Research funds; Management; Countermeasure

\begin{abstract}
Scientific and technological progress and innovation is the main driving force to promote the development of social economy. With the increasing emphasis on researching, research funding for the private colleges and universities has become a part of the source of funding for private colleges, and research funding management in private colleges and universities in the financial management of the status has becoming increasingly significant. How to standardize the management and use of research funding, has become an important issue for the private universities to study and solve. Based on the analysis of specific problems found in scientific research funds management in private colleges and universities, this paper puts forward some countermeasures of solving the problems to improve the scientific management level and to accelerate the development of private universities.
\end{abstract}

\section{Introduction}

With the reform and opening up, China's private education has been developing rapidly. As the private school running mechanism and mode of operation of the full-time ordinary institutions of higher learning private colleges and universities have become an important part of higher education in our country, which is the innovation and development of China's higher education mode in the new period.

Private colleges and universities' carrying out scientific research work, not only lays a solid foundation for improving the level of teachers and the quality of education, but also guarantees the scale and the upper level of private colleges and universities. With the economy development, science and technology has been changing constantly with each passing day and the function of scientific research in colleges and universities is becoming increasingly important. Scientific research has become an important symbol of the improvement and quality of modern university education. Private colleges and universities have also paid closer attention to research work. However, in terms of the management of scientific research funds, there is a big gap between public colleges and universities and private colleges and universities. Private colleges and universities owing to its late starting. Only by strengthening the scientific research funds management and constantly improving the level of teachers' scientific research can private colleges and universities strengthen the faculty of the college and improve the quality of teaching fundamentally, thus cultivating more practical talents and promoting the healthy development of private colleges and universities themselves.

Therefore, how to strengthen the implementation of the budget and final accounts of scientific research funds and how to regulate the management and use of scientific research funds have become the important issues that need to be studied and solved at present. This paper puts forward practical solutions to the specific problems found in the management of scientific research funds in private colleges and universities, so that to supervise and draw lessons from the management of scientific research funds. 


\section{The Main Problems Existing in the Management of Scientific Research Funds in Private Colleges and Universities}

In order to promote the rapid growth of scientific research funds, private colleges and universities take the loose management policy, which leading to the researchers do not have a clear understanding of the ownership of the funds and any arbitrage and transfer of funds and other phenomena occur from time to time [1]. Meanwhile, a large amount of research funding are lost, which did not achieve the desired effect.

The Budget of Scientific Research in Private Colleges and Universities is not Reasonable. Part of the research staff of private universities do not attach importance to the budget, or lack of experience in project host acceptance. When they are writing application and planning task book, they don't have a clear understanding of the project budget. In the planning task book, there is no investigation and scientific research and have no financial staff involved in calculating expense in most cases, which is basically decided by the subject of host subjective intention or so-called others to declare success experience just up the numbers, thus the budget and the actual expenditure is not consistent all too often in the operating process. Due to the large distinction, a multitude of project budget funds are not guaranteed. However, some budget funds do not know how to be spend, finally it will affect the smooth implementation of the project and the implementation of the effect.

The Management System of Scientific Research Funds in Private Colleges is not Perfect. Since the start of the private colleges and universities, there has been a phenomenon of paying little attention to research but thinking highly of teaching [2]. For the management of teaching funds, private colleges and universities have already formed a set of relatively complete regulations on the use of funds and the allocation system. But for the management of scientific research funds, because the number is extremely small, funding in place of the time cannot be determined with no corresponding management experience, unlike public colleges and universities as the formation of the regular and efficient system. In daily work, the management system of educational funds is often applied to the management system of scientific research project funds. Since there are many differences between the funding of teaching management system and scientific research activities abided by the project funds management system, if there is a lack of understanding of the variability and complexity of research activities, various problems will arise in actual work. it is difficult to scientifically and effectively guide and supervise the use of funds for scientific research projects, which affects the conclusion of scientific research [3,4].

The Implementation of Scientific Research Funds in Private Colleges and Universities is not Strict. Some colleges and universities do not strictly abide by the "earmarking" principle. On the contrary, they even misuse and misappropriate research funds. There are a lot of colleges and universities use research funding illegally, such as acquire general equipment with scientific research funds, including contract agreement, the purchase of computers, electronic dictionaries, mobile phones, air conditioning, etc. Some others regulate the college office supplies, cleaning fee, charger, newspapers and other public expense into the design costs, material costs and direct cost subject in the directly included way, or they classify assessment fees, lecture fees and personnel fees issued to the unit's internal personnel into the cost of special research.

Private Colleges and Universities Research Funding Settlement Is Not Timely. Generally speaking, when a project is completed, the financial sector evaluates the funding for the project by the relevant departments of the knot through the notice. But in reality, in most cases, research expenditures do not check processing. It seems that the subject hasn't timely concluding and long-term losses are surplus funds, because most of people who responsible for the research have little understanding of the financial management knowledge and management system, it brings the certain difficulty to the financial management.

The balance of scientific research funds cannot be allocated, which is not only wastes limited educational resources, but also increases the burden of the task of the financial staff of private colleges and universities in accounting and financial management. 


\section{Measures for Strengthening Standardized Management of Scientific Research Funds in Private Universities}

To Strengthen the Budget Management of Scientific Research Funds, and Gradually Establish A Performance Evaluation System of Scientific Research Funds. It is high time that private colleges and universities changed the current extensive management of research funds. Teachers and other staff should invite experienced teachers in colleges and universities and financial personnel to explain how to refine the scientific research project funds budget, reasonable planning, budget detailed budget subjects while writing task application and plan. For subjects of the budget that is not reasonable and scientific, they shall not be declared. The project team that has been set up should be strictly in accordance with the plan of expenditure budget (But as for the research needs of the project, in the case of a reasonable expenditure of funds, it is allowed to correct research projects in the task book budget plan)[5]. The financial and scientific research departments should control and process strictly from the source, set up inspection teams, regular review of expenditure of research funds and identify problems and correct it timely. It's also necessary to establish the performance evaluation system of scientific research funds, to encourage staff to take high level issues, and gradually establish scientific research funds performance evaluation system, to assess and evaluate the scientific research that has made economic and social benefits, and gradually create respect for scientific research, pay attention to the good environment of scientific research personnel, to the individual who have made outstanding contributions in scientific research and achieved remarkable social and economic benefits, the school should give priority in the title declaration, annual assessment, awarding and evaluation, performance salary etc., and accordingly improve living conditions, improve housing conditions, the formation of "teaching with scientific research, scientific concept of teaching with scientific research, and continuously improve the scientific research in private universities the funds management level.

Establish and Improve the Management System of Scientific Research Funds in Private Universities and Strict Implementation. Private colleges and universities ought to comprehensively analyze China's laws, regulations and related policies, grasp the dynamic in the forefront of scientific research, and follow the objective laws and characteristics of scientific research. Combined with the actual situation of the school, it is wise to establish and improve research project funds management system which has the clear index, is easy to operate and is rigorous scientific. Scientific research funds management system is comprehensive, including scientific research project funds using standard, the scope and amount, the responsibilities of the financial and scientific research departments, scientific research personnel's rights and obligations, also involve all aspects of the financial management. The management system of scientific research funding should be authoritative, which needs financial and scientific research departments, scientific research personnel to strictly abide by the common maintenance system. For those who violate the regulation should be investigated, accountability. According to regulations, the scientific research funds should implement "separate accounts, earmarking" principle and expenditures must be strictly in accordance with the budget and the provisions of the state of the scope and level of expenditure charged. It is strictly prohibited for issues unrelated to the expense in the project funds, scientific research funds for other purpose $[6,7] \mathrm{s}$. It is necessary to further clarify authorities and their duties on the university scientific research departments, financial departments and the project person in charge of the scientific research project funds and to cooperate closely and jointly do a good job in the work of management of scientific research funds. The specific process as shown in Figure .1[8] 
1. The funds accounted for

2. Adjustment of scientific research

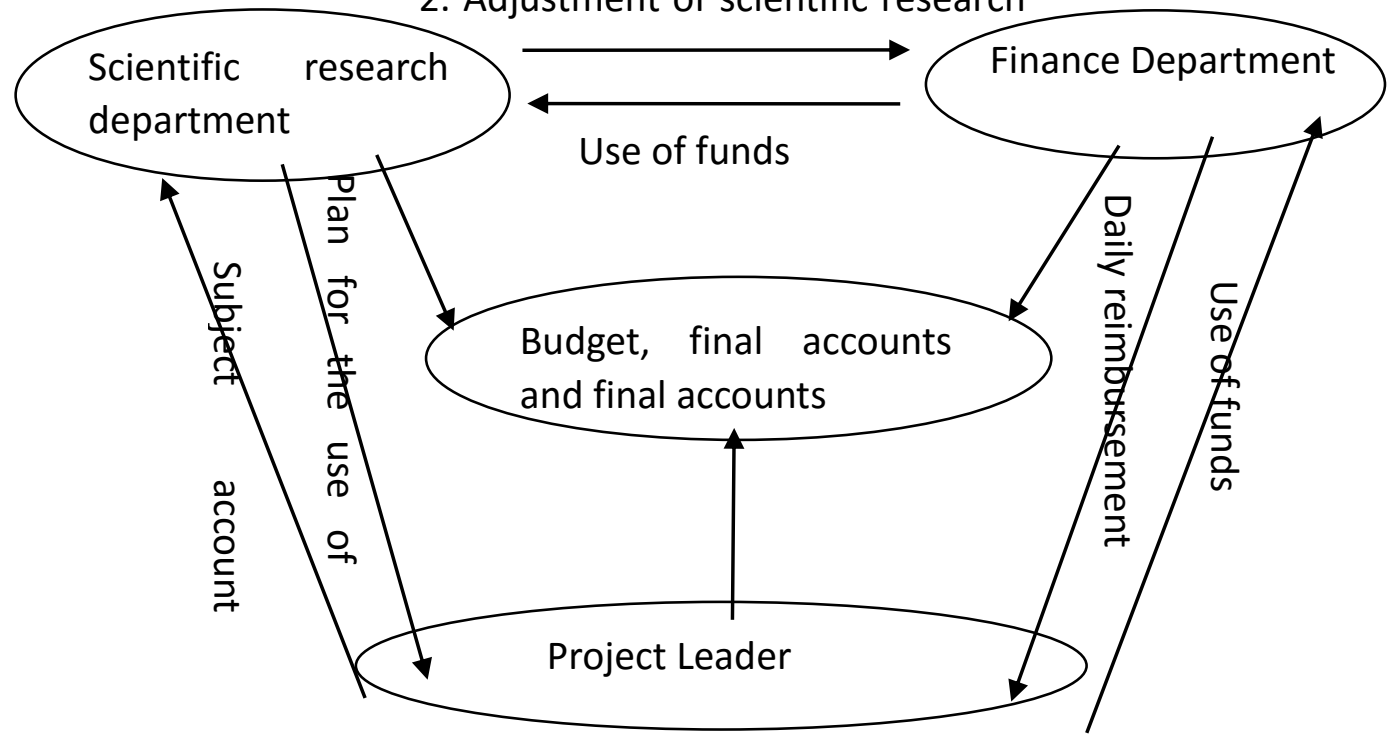

Figure 1. Project leader, research department, finance department, the three party relations

To Strengthen the Management of The Balance of Research Topics, and Improve the Management of the Project Funds to Settle Accounts. Balances for each subject account for a small proportion of the scientific research project funds, but the overall number is large. It is significant how to regulate subject balance of funds management for private funding and university research project management. To manage the chaotic situation of the balance of the subject, we must formulate the management method of the funds for scientific research projects. Provisions on the specific steps, requirements and deadlines for the payment of funds in the management of the fund for scientific research projects is also a must, which can be applied to guide the balance of funds to guide the check, clearing and cleaning work, while improving the balance of the project funding procedures. At the same time, in order to improve the project budget surplus inventory program, we must prevent the occurrence of phenomenon and indiscriminate use of subject balance of funds for other purposes from the procedure and system security fund balance accounting subject standard. We can also use computer network technology to establish scientific research topic, fund management system and strengthen the exchange of scientific research management information, timely understanding of the research progress and funds usage information and closely monitor the scientific research project funds checkout situation. Financial personnel should actively communicate with the scientific research personnel and prompt service, mentioning the validity of the scientific research personnel before the checkout. For those who settle the balance of funds, we should give them appropriate incentives [9,10].For those without any justifiable reason overdue for the settlement of the research topic, the Institute has the right to settle accounts according to the scientific research project funds management approach, maximizing the effectiveness of the limited research funding.

\section{Summary}

Private colleges and universities is not only an indispensable part of higher education in our country, but also one of the forces for a country in scientific research.

Whether the research funds management is standard and perfect or not, it determines whether the research funding can get reasonable and efficient use, and thus will affect the development of national scientific research quality and scientific research institutions [11]. 
Therefore, we should combine the national policy research with whole range of reforms, improvement in internal management mechanism in colleges and universities and improvement of micro- management measures in task group, which can solve the problem of scientific research in private colleges and universities in the process of management and further improve the efficiency and effectiveness of scientific research in private colleges and universities work.

\section{References}

[1] Huang xuefei. Scientific research management in colleges and universities of J. Accounting communications, 2011 (2)

[2] Wang Peng. Research on the efficiency audit of scientific research funds in Colleges and universities [J]. Journal of Changchun University of Science and Technology, 2012 (12)

[3] Wang Jian, Jia Xiumei, Wang Shu. Thinking about the scientific research funding in Colleges and universities (J). Education and finance research, 2011 (2)

[4] Liu Haili. Research on the management of scientific research funds in Institutions of higher learning (J). Friends of accounting, 2012 (27)

[5] Mu Jie, Luan Zhongquan, Yan Weimin, Yan Jian. Study on the current situation and Countermeasures of scientific research management work of colleges and universities in areas -- Taking Beijing University of information science and technology as an example [J]. Journal of Beijing Institute of machinery, 2008 (9)

[6] Xue Fengrong. A preliminary study on the standardized management of scientific research funds in Colleges and universities (J). Educational auditing, 2012 (2)

[7] Wang Songnian [M]. The international forefront of accounting. Shanghai University of Finance and Economics press, 2005

[8] Du Jingshun. Reflections on strengthening and improving the management of scientific research funds in Colleges and universities J. Journal of Shenyang Agricultural Uinversity, $2010(3)$

[9] the Ministry of education opinions on Further Strengthening the management of university scientific research project (Educational Technology 2012 No. 14 S.2012-12-18

[10] Xie Haibo. Problems and Countermeasures in the management of scientific research funds in Colleges and universities (J). Journal of Yanshan University, 2011 (6)

[11] Huang Hongjie, Ding Newfarmer. Strengthen the management of scientific research funds in J University. Friends of accounting, 2011 (9) 